Original Article

\title{
Homeopathic treatment of vaginal leiomyoma in a dog: case report.
}

\author{
Maria Ignez Carvalho Ferreira(MSc), Luiz Figueira Pinto (PhD)
}

Universidade Federal Rural do Rio de Janeiro (UFRRJ), RJ, Brazil

\begin{abstract}
The most common vaginal neoplasias in old dogs are leiomyoma and fibroma. Although surgical excision is the indicated treatment, it does not eliminate potential complications that may lead to death or poor quality of life. This paper reports the case of a 9 year-old female Doberman dog with vaginal leiomyoma attended by copious and recidivating colporrhagia homeopathically treated between March and December 2005. Homeopathic approach was the one designed at Homeopathic Unit of the Veterinary Hospital, Rural Federal University of Rio de Janeiro, Brazil. The progress of disease was assessed through clinical evaluation, laboratory exams and ultrasonography. Hemorrhage decreased while the general clinical state of the animal improved. After 7 months of homeopathic treatment, the tumor was spontaneously eliminated through violent abdominal contractions, which was followed by recovery of the animal's state of health.
\end{abstract}

Keywords: Homeopathy; Veterinary medicine; Tumors; Leiomyoma; Vaginal; Dogs

\section{Introduction}

Neoplasias of the female genital system in dogs are rare [1] and occur mainly in old animals [2,3]; early detection is difficult as in most cases, coexistent chronic diseases mask the initial signs of neoplasia [4-6]. The main tumors involved are leiomyoma and fibroma, that may develop in extraluminal mode and therefore, affect the function of neighboring organs [7].

Surgical excision is the first therapeutic choice when total ablation is possible [8] and can be associated to castration [9]. Radio- and chemotherapy, alone or associated to surgery had also been employed, with low therapeutic rates of success [10-13]. In such cases, survival time and duration of remission show unfavorable rates in old animals [14].

Homeopathic therapy has been used to revert adverse effects of chemo and radiotherapy [15-17], improve quality of life $[18,19]$ and as specific treatment of some tumors, e.g. chondrosarcoma [20], skin neoplasias [21] and malignant hystiocitoma [22].

Reports of homeopathic treatment of human female genital tumors point out to favorable outcomes in uterine fibroma, with decrease of pain and endometrial hemorrhage [23], and leiomyosarcoma [24].

It is presented the report of a case of vaginal leiomyoma in an old dog subjected to homeopathic treatment.

\section{Case Report}

9 year-old Doberman female dog presenting leiomyoma, followed up from March to December 2005. Homeopathic approach was the one described by Pinto [25] Homeopathic prescription was based on the correlation of the clinical homeopathic diagnosis and the clinical, repertory and pathogenetic picture presented by the patient.

Main complaint was vaginal bleeding. The animal had presented an initial episode of copious colporrhagia in April, 2004, a tumoral mass was then detected on the vaginal floor.

Ultrasonography revealed the presence of a heterogenous mass in the vaginal canal, measuring $15 \times 4.5 \mathrm{~cm}$, extending from the vaginal fornix to the vestibule. (Figure 1). 
Since that moment, the patient had present repeated episodes of colporrhagia, which had not improved with neither conventional nor homeopathic (Arnica montana 6cH, Cactus grandiflorus $1 \mathrm{cH}$ and Phosphorus 100cH) treatments. It was brought to our clinic in March 2005, presenting new colporrhagia episodes. The owner told that such episodes tended to occur most frequently in the evening and were preceded by a state of physical restlessness and followed by prostration. The animal was also sensitive to changes in climatic conditions; urination and evacuation required intense strain.

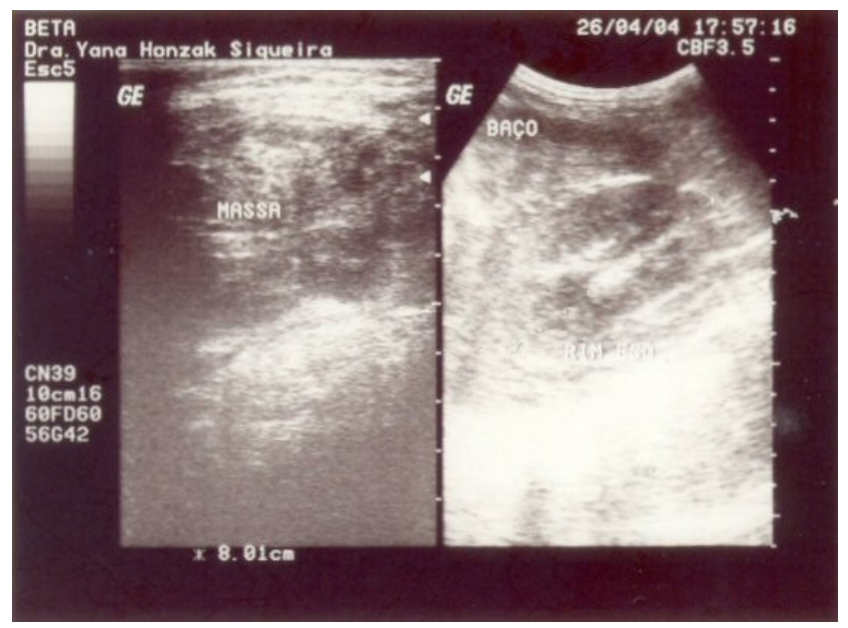

Figure 1: USG disclosing vaginal heterogeneous mass with $15 \mathrm{~cm} \times 4,5 \mathrm{~cm}$ of dimension.

Table 1: Clinical symptoms and repertory correlations [39].

\begin{tabular}{|l|l|}
\hline Clinical symptoms & Repertory rubrics \\
\hline It is always near the owner & Mind, Company, desire of \\
\hline Urinary retention & Bladder, Retention urine \\
\hline $\begin{array}{l}\text { Vaginal tumoral mass } \\
\text { Copious vaginal bleeding of dark blood with clots. }\end{array}$ & $\begin{array}{l}\text { Feminine, Metrorrhagia, fibromas by* } \\
\text { Feminine, Dark metrorrhagia blood* } \\
\text { Feminine, Metrorrhagia clots* } \\
\text { Feminine, Tumors vagina }\end{array}$ \\
\hline $\begin{array}{l}\text { Constipation } \\
\text { Bleeding } \\
\text { Dark blood with coagulum } \\
\begin{array}{l}\text { Change of weather aggravates } \\
\text { Tumor }\end{array}\end{array}$ & $\begin{array}{l}\text { Rectum, Constipation, difficult defecation } \\
\text { Generalities, Hemorrhage dark blood } \\
\text { Generalities, Hemorrhage blood coagulum } \\
\text { Generalities, Weather changes agg. } \\
\text { Generalities, Tumors fibroma hemorrhagic }\end{array}$ \\
\hline
\end{tabular}

Physiological antecedents disclosed the patient was primipare, proestrus characterized by intense hemorrhage and estrus, by intense tumefaction of the vulva. The animal had been subjected to standard medical prophylaxis procedures, including quarterly use of vermicides and vaccinations (rabies, cinomosis, hepatitis, leptospirosis, canine coronavirus, canine parvovirus, influenza, tetanus and canine infectious tracheobronchitis). Previous illnesses included giardiasis attended with enterorrhagia (in 1996), ehrlichiosis and cervical caudal subluxation - Wobbler's syndrome (in 2001) and pyometritis with castration (in 2002). 
Among significant familiar antecedents, the animal's mother had died at age 11 from congestive cardiac insufficiency and had also presented mammary neoplasia. Its father had been sacrificed at age 9, due to hypothyroidism, generalized pyodermitis and septicemia. Our patient had cohabited with other dogs of the same race and had received regular veterinary care.

Examination showed a very aggressive animal, of a peculiar racial biotypology with well developed muscles and bones; round trunk; bones in limbs had low development and presented support in hyperextension; the costo-sternal angle was less than $90^{\circ}$. The animal presented paleness of tongue, oral and ocular mucosae. Presence of copious colporrhagia of dark blood with clots, preceded by intense abdominal contractions attended with moaning.
Examination with speculum revealed the presence of a projected tumoral mass in the vaginal canal.

On these grounds, the following diagnoses were established: 1) Clinical: vaginal tumor and Wobbler's syndrome; 2) Dynamic clinical prognosis : severely lesional / incurable; 3) Biopathographical factors: previous illnesses, hysterectomy and vaccinations; 4) Biotypological: mixed phosphoric and carbonic constitution; 5) Temperamental: atrabiliary; 6) Diathesic: sycosis.

Therapeutic priority was given to genital hemorrhage. Selection and analysis of symptoms are presented on Table 1; resulting remedies, in Table 2. Clinical management and evolution are described in Table 3.

Table 2: Repertory analysis (Coverage/Punctuation) [39]

\begin{tabular}{|l|l|l|l|}
\hline \multicolumn{4}{|l|}{ Homeopathic Medicines (covering/punctuation.) } \\
\hline Phosphorus 10/19 & Nitricum acidum 10/16 & Sulphur 9/17 & Lycopodium $9 / 15$ \\
\hline Mercurius solubilis $9 / 14$ & Calcarea carbonica $8 / 15$ & Sabina $8 / 13$ & Sulphuric acidum $8 / 10$ \\
\hline Platina $7 / 14$ & Silicea $7 / 13$ & Secale cornutum $7 / 11$ & Calcarea phosphorica $5 / 8$ \\
\hline Chamomilla $5 / 8$ & Thlaspis bursa pastoris 5/8 & Trillium pendulum 4/6 & Hydrastis canadensis $3 / 5$ \\
\hline
\end{tabular}

\section{Discussion}

The clinical diagnosis of vaginal leiomyoma grounded on clinical examination and ultrasonography was confirmed by histologycal analysis [26].

Development of leiomyoma in females is influenced by sexual hormones [27], which may explain the relatively low occurrence of vaginal neoplasias in castrated dogs $[1,28]$.

However, in our case, although the dog was castrated, a tumoral mass developed causing mechanical interference on the adjacent structures resulting in urine retention and constipation, which are rare occurrences [7].

Surgery was not performed due to the size and localization of the tumor, that made complete excision impossible, whereas the age and clinical state of the patient added risk factors [7,29-31].

From a strict homeopathic standpoint, some considerations are in order. First, the atrabiliary temperamental condition of the patient established on the basis of lack of plasticity and tonicity - inherent to its age and ongoing disease [32] contributed to decide for a homeopathic treatment in this case, even though a previous homeopathic approach, different from ours, had failed.

Then, although the current stage of the disease, as well as its localization, the age of the patient and the clinical state indicated poor prognosis (severely lesional/incurable from a dynamic point of view), the homeopathic treatment resulted in full remission, against our initial expectation. 
Table 3: Clinical management and evolution

\begin{tabular}{|c|c|c|}
\hline Date & Clinical evolution & Prescription \\
\hline 3/3/05 & & $\begin{array}{l}\text { Euphorbia tirucalli } 6 \mathrm{cH} \\
+ \text { Thlas } 6 \mathrm{cH}+\text { Myoma } \\
6 \mathrm{cH}, 5 \text { drops, once daily } \\
\text { for } 1 \text { month. }\end{array}$ \\
\hline $3 / 4 / 05$ & Bleeding stopped, faster than with previous treatments. & \\
\hline 3/6/05 & Colporrhagia returned. & $\begin{array}{l}\text { Addition of Phos } 6 \mathrm{cH} . \\
\text { Bleeding stopped } 2 \\
\text { hours after. }\end{array}$ \\
\hline $6 / 21 / 05$ & $\begin{array}{l}\text { Colporrhagia returned. } \\
\text { Asked complete blood analysis. }\end{array}$ & No medication \\
\hline $10 / 10 / 05$ & Steady clinical state with occasional bleeding. & $\begin{array}{l}\text { Myoma } 6 \mathrm{cH}+\text { Nit-ac } \\
6 \mathrm{cH} 5 \text { drops, once daily } \\
\text { for } 15 \text { days. }\end{array}$ \\
\hline $10 / 18 / 05$ & Leukorrhea followed by intense bleeding. & Medication kept \\
\hline 10/23/05 & $\begin{array}{l}\text { Episode of copious colporrhagia; yellow-green nasal secretion of odd } \\
\text { odor, with formation of adherent crusts. }\end{array}$ & $\begin{array}{l}\text { Thlas } 6 \mathrm{cH}+\text { Euph-t } 6 \mathrm{cH} \\
5 \text { drops, once daily for } 6 \\
\text { days. }\end{array}$ \\
\hline $10 / 26 / 05$ & Fetid leucorrhea & $\begin{array}{l}\text { Owner gave } \\
\text { enrofloxacin for } 3 \text { days }\end{array}$ \\
\hline $10 / 29 / 05$ & $\begin{array}{l}\text { Fetid leucorrhea persists; abdominal contractions as from childbirth } \\
\text { followed by vaginal elimination of } 2 \text { tumoral masses }(12 \mathrm{x} 4 \mathrm{~cm} \text { and } 3.5 \mathrm{x} \\
2.5 \mathrm{~cm} \text { ) of firm consistency and an area of necrosis in the grain stalk of } \\
\text { the larger one, with discrete bleeding. (Figures } 2,3 \text {, 4). Material was } \\
\text { collected for hystopathological analysis: leiomyoma. Ultrasonography: } \\
\text { no alterations (figure 5). }\end{array}$ & Myoma $6 \mathrm{cH}$ for 15 days \\
\hline $11 / 4 / 05$ & $\begin{array}{l}\text { Good clinical conditions, but urinary incontinence; some bleeding in the } \\
\text { mornings. }\end{array}$ & $\begin{array}{l}\text { Thlas } 6 \mathrm{cH} \quad 5 \text { drops in } \\
\text { single dose. }\end{array}$ \\
\hline $11 / 5 / 05$ & Good clinical state; urinary incontinence. & No medication. \\
\hline $12 / 27 / 05$ & No complaints, good clinical conditions. & Discharge \\
\hline
\end{tabular}

Third, biopathographical data pointed out to luetic (giardiasis, erlichiosis) and sycotic (pyometritis, leiomyoma) antecedents [25]. Wobbler's syndrome has no diathesic classification yet. Therefore, this patient had suffered in its past from a luetic-sycotic interaction, leiomyoma as ongoing disease pointed out to a functional prevalence of sycosis, which helped in the selection of the suitable homeopathic remedies [25]. The mixed phosphoric - carbonic biotypological constitution was of racial and not of adaptative origin. This occurrence may point out to structural incompatibilities between diathesis reactivity patterns. This notion reinforces the need to deal with this kind of clinical situations with antisycotic homeopathic remedies [33].

The main circumstantial medicine chosen among those indicated by repertory analysis was Thlaspis bursa pastoris. This remedy was compatible with both the main complaint and diathesis of the patient, as it is indicated in genital hemorrhages associated to tumors [25,34]. Alternation of Thlaspis 
bursa pastoris with Euphorbia tirucalli and Myoma might be the responsible for the clinical recovery of the patient, as the former is used in the treatment of cancer and its clinical complication [36] and regarding the latter, biotherapic may be used, in general, as immunomodulators [37].

After 7 months of using those remedies, Nitricum acidum was introduced, as a remedy directed against sycosis. This, however, elicited worsening of the hemorrhage and the general state; for this reason it was discontinued after 13 days of use and the earlier therapeutic scheme was introduced.

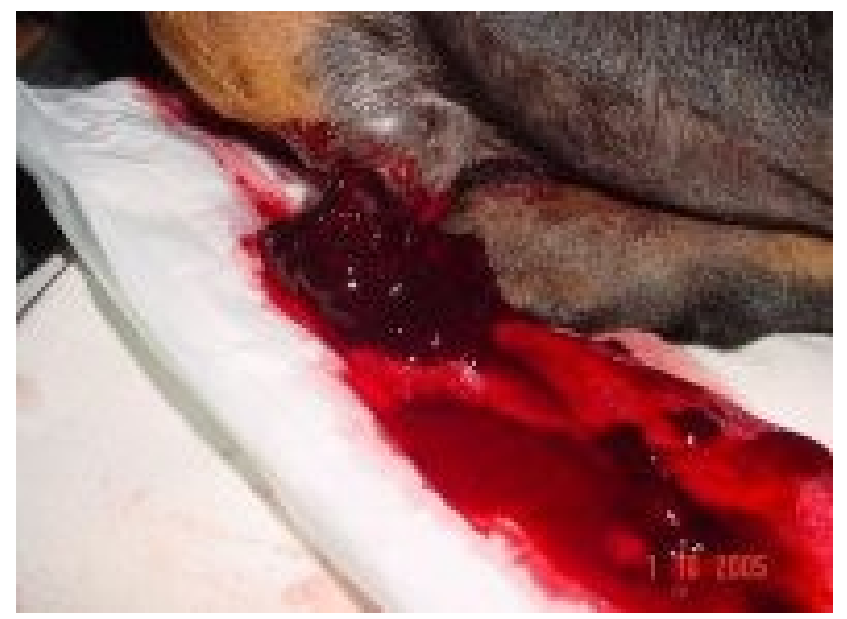

Figure 2: colporrhagia with dark coagulum.

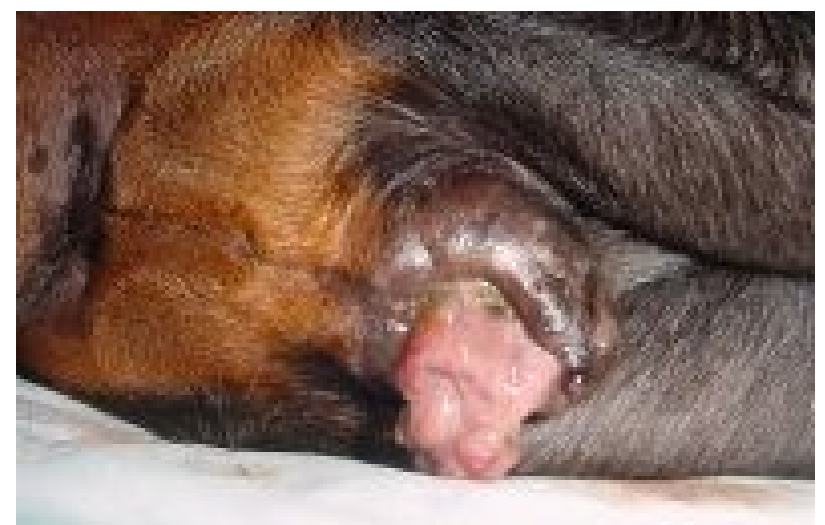

z 10805

Figure 3: protrusion of tumoral mass through vulva.
Complete clinical recovery occurred 6 days after discontinuance of Nitricum acidum and spontaneous elimination of the tumoral mass. These chronology supplies strong indexes to suspect that it was this same remedy which promoted the defining event, which is strengthened by the fact that Nitricum acidum has particular action on genital neoplasias which bleed on the slightest contact [35] and there are reports of its efficacy in the treatment of genital tumors [23,38]. There are not reports in the literature about therapeutic ejection of leiomyoma in dogs.

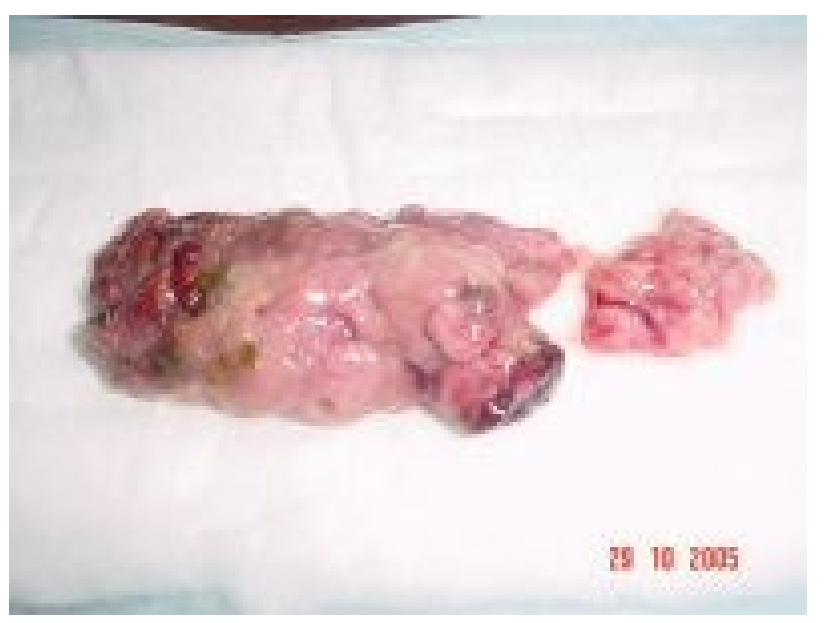

Figure 4: tumoral mass after elimination with area of necrosis in the grain stalk.

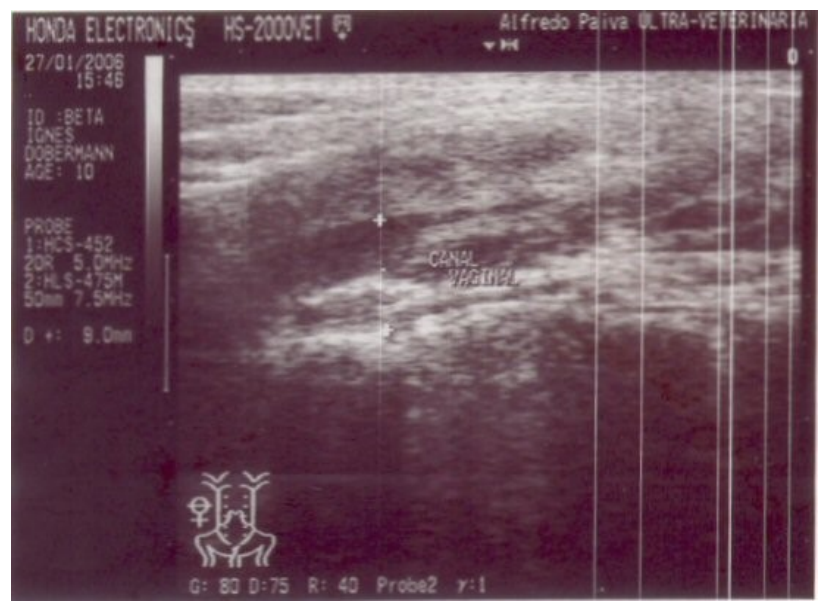

Figure 5: USG showing linear vaginal canal with preserved and regular walls, without ecographic alteration. 


\section{Conclusions}

The favorable outcome in this case shows that homeopathy may be a valuable resource in the treatment of vaginal tumors in dogs. This is particularly significant as conventional treatment had failed and surgery was not a viable option.

On the other hand, this case constitutes one further evidence for our therapeutic protocol, in the face of its success and the failure of earlier homeopathic treatment grounded on other considerations.

\section{References}

[1] Soderberg SF. Vaginal disorders. Vet Clin North Am Small Anim Pract. 1986; 16(3): 543-559.

[2] Dorn CR, Priester WA. Epidemiology. In: Theilen GH, Madewell BR, editors. Veterinary Cancer Medicine. $2^{\text {nd }}$ ed. Philadelphia: JB Lippincott; 1987. 14-32.

[3] Silverberg E, Lubera JA. Cancer statistics. Cancer. 1988; 38: 11-23.

[4] Morrison WB. Diagnosis and treatment of cancer in aged animals. Veterinary Vet Clin North Am Small Anim Pract. 1989; 19: 137-154.

[5] Robie PW. Cancer screening in the elderly. J Am Geriatr Soc. 1989; 37: 888-893.

[6] Kitchell BE. Cancer therapy for geriatric dogs and cats. J Am Anim Hosp Assoc. 1993; 29: 41-48.

[7] Grooters AM. Ovariopatias e uteropatias. In: Birchard SJ, Sherding RG, editors. Manual Saunders: Clínica de pequenos animais. São Paulo: Roca; 1998. 125-136.

[8] Salomon JF, Deneuche A, Viguier E. Vaginectomy and urethroplasty as a treatment for non-pedunculated vaginal tumours in four bitches. $J$ Small Anim Pract. 2004: 45(3):157-161.

[9] Thacher C, Bradley RL. Vulvar and vaginal tumors in the dog: a retrospective study. J Am Vet Med Assoc. 1983; 183(6): 690-692.

[10] Begg CB, Carbone PP. Clinical trials on drug toxicity in the elderly. Cancer. 1983; 52: 1986-1992.

[11] Aucoin DP. Drug therapy in the geriatric animal: The effect of aging on drug disposition. Vet Clin North Am Small Anim Pract. 1989; 19: 41-48.

[12] Phister JE, Jue SG. Cusack, B.J. Problems in the use of anticancer drugs in the elderly. Drugs. 1989; 37: 551-565.
[13] Balducci L, Mowrey K, Parker M. Pharmacology of antineoplastic agents in older patients. In: Balducci L, Lyman GH, Ershler WB, editors. Geriatric Oncology. Philadelphia: JB Lippincott Co; 1992. 169-180.

[14] Holmes FF. Clinical evidence for change in tumor aggressiveness with age. In: Balducci L, Lyman GH, Ershler WB, editors. Geriatric Oncology. Philadelphia: JB Lippincott Co; 1992. 223-227

[15] Thompson EA. Using homeopathy to offer supportive cancer care, in a National Health Service outpatient setting. Compl Ther Nurs Midwifery. 1999; 5(2): 37-41.

[16] Balzarini A, Felisi E, Martini A, De Conno F. Efficacy of homeopathic treatment of skin reactions during radiotherapy for breast cancer: a randomized, double-blind clinical trial. British Homeopathic Journal, 2000; 89 (1): 8-12.

[17] Mark P. Carcinoma of breast and panic attacks. British Homeopathic Journal. 2000, 89(1): 35-36.

[18] Bradley GW, Clover A. Apparent response of small cell lung cancer to an extract of mistletoe and homeopathic treatment. Thorax. 1989; 44 (12): 10471048.

[19] Spence DS, Thompson EA, Barron SJ. Homeopathic treatment for chronic disease: a 6 year, university-hospital outpatient observational study. J Alternative Compl Med. 2005; 11: 793-798.

[20] Phillips WG, Grant J, Calonje JE. Chondrosarcoma of the finger. J Pathol. 1996; 178: $56 \mathrm{~A}$.

[21] Metzger H, Kurtz B, Ahlemann L. Osteolytic bone manifestations in mycosis fungoides. Rofo. Fortschr Geb Roentgenstr. Neuen. Bildgeb. Verfahr. 1980; 133(3): 331-333.

[22] Jesus MH, Costa LR, Cardoso ES. Conium maculatum in the treatment of histiocytoma in canis familiaris. Revista do IHB. 1992; 1(1): 41-44.

[23] Popov AV. Homoeopathy in treatment of patients with fibromyoma of the uterus. British Homeopathic Journal. 1992; 81(4): 164-167.

[24] Montfort, H. A new homeopathic approach to neoplastic diseases: from cell destruction to carcinogen induced apoptosis. British Homeopathic Journal. 2000; 89(2): 78-83.

[25] Pinto LF. Homeopathic veterinary clinical protocol. In: Bonamin LV, editor. Signals and images II: contributions and contradictions about 
high dilution research. New York: Springer; 2008. 185-211.

[26] Cain JL, Davidson AP. Sistema reprodutivo e próstata. In: Goldston RT, Hoskins JD, editors. Geriatria e gerontologia cão e gato. São Paulo: Roca; 1999. 345-356.

[27] Miettinen M, Fetsch JF. Evaluation of biological potential of smooth muscle tumors: Review. Histopathology. 2006; 48(1): 97.

[28] González Cruz G, Sánchez Buitrago CA, Vélez Hernández ME, Buen Nade. Neoplasias en aparato reproductor en perras: estudio restrospectivo a 6 años / Neoplasias in the reproductive system in female dogs: retrospective study of 6 years. Veterinária Méx. 1997; 28(1): 31-34.

[29] Harvey HJ. Surgery. In: Theilen GH, Madewell BR, editors. Veterinary Cancer Medicine. $2^{\text {nd }}$ ed. Philadelphia: JB Lippincott Co;1987. 136-149.

[30] Withrow SJ. Surgical oncology. Clinical Veterinary Oncology. Withrow SJ, Macewen EG, editors. Philadelphia: JB Lippincott Co; 1989.

[31] Tanaka R, Hoshi K, Yamane Y. Partial bladder resection in a bitch with urinary retention following surgical excision of a vaginal leiomyoma. J Small Anim Pract. 2001; 42(6): 301-303.
[32] Kossak-Romanach A. Homeopatia em 1000 conceitos. 3 $3^{\text {rd }}$ ed. São Paulo: Elcid; 2003.

[33] Carillo Junior, R. Homeopatia, medicina interna e terapêutica. São Paulo: Livraria Editora Santos; 2000.

[34] Kuroda K, Akao M, Kanisawa M, Miyaki K. Inhibitory effect of Capsella bursa-pastoris extract on growth of Ehrlich solid tumor in mice. Canc Res. 1976; 36: 1900-1903.

[35] Vannier L, Poirier J. Tratado de matéria médica homeopática. 9th ed. São Paulo: Andrei; 1987.

[36] Varricchio MCBN, Pinto LF, Andrade EM, Pellagio SS. Emprego do Avelós (Euphorbia tirucalli) dinamizado no tratamento do câncer. Homeopat Bras. 2000; 6(1): 64-67.

[37] Pinto, LF. Bioterápicos. Rio de Janeiro: Instituto Hahnemaniano do Brasil; 2007.

[38] Buchi DF, Del Vecchio M. Qualidade de vida para pacientes com câncer e Aids. Mita'y. 2002; 1: 33-38.

[39] Favilla JP. SIHORE: Sistema de Homeopatia Repertorial Versão 2004 [CD-Rom]. São Paulo; SIHORE; 2004.

\section{(c)) EY-NC-ND Licensed to GIRI}

Support: authors declare that this study received no funding

Conflict of interest: authors declare there is no conflict of interest

Received: 22 August 2008; Revised 05 September 2008; Published: 15 September 2008

Erratum: 30 Dec 2008. (http://www.feg.unesp.br/ ojs/zacha_ijhdr/erratum/?v=7\&i=24\&pi=152)

Correspondence author: Luiz Figueira Pinto. luizfigueira@ufrrj.br

How to cite this article: Ferreira MIC, Pinto LF. Homeopathic treatment of vaginal leiomyoma in a dog: case report. Int J High Dilution Res [online]. 2008 [cited YYYY Mmm DD]; 7(24):152-158. Available from:

http://www.feg.unesp.br/ ojs/index.php/ijhdr/article/view/304/358. 